\title{
STRATEGI PEMBELAJARAN BERBASIS MASALAH UNTUK MENINGKATKAN KOMPETENSI DASAR FISIKA SISWA KELAS VIII SMP AMIR HAMZAH MEDAN
}

\author{
Lia Afriyanti Nst \\ Universitas Muslim Nusantara Al - Wasliyah
}

\begin{abstract}
ABSTRAK
Penelitian ini dilaksanakan dengan tujuan meningkatkan kompetensi dasar Fisika dan aktivitas siswa SMP, melalui penerapan strategi pembelajaran berbasis masalah. Penelitian tindakan kelas ini dilaksanakan dalam dua siklus pembelajaran, melibatkan 40 orang siswa kelas VIII - 1 SMP Amir Hamzah Medan. Kompetensi dasar Fisika yang disasar meliputi aspek kognitif, psikomotor dan afektif. Data tentang kompetensi kognitif dikumpulkan dengan metode tes, menggunakan pemahaman konsep, data tentang kompetensi psikomotor dan kualitas aktivitas pembelajaran siswa dikumpulkan dengan metode observasi menggunakan pedoman observasi, sedangkan data tentang kompetensi afektif siswa dikumpulkan dengan metode kuesioner menggunakan angket. Semua data penelitian kemudian dianalisis secara deskriptif dengan menentukan rererata masingmasing data dan dijustifikasi pada masing-masing indikator. Hasil analisis data menunjukkan bahwa kompetensi dasar Fisika siswa dapat ditingkatkan.
\end{abstract}

Kata kunci : pembelajaran berbasis masalah, kompetensi dasar Fisika, dan aktivitas

\begin{abstract}
The purposes of this action research were to increase the basic competency of physics and the quality of the student's learning activity, through implementing the problem based learning strategy. The action research was conducted in the two cycles, involving 40 students of the eighth class of SMP Amir Hamzah Medan. The physics basic competency included the cognitive, the psychomotor, and the affective competency. The cognitive competency data was collected by the test method using the concept-understanding test. Both the data of the psychomotor competency and quality of student's activity in learning were collected by observation method. While the affective competency data was collected using questionnaire. All of the research's data were analyzed descriptively by finding their average score and were justified to each indicator. The results indicated that the student's physics basic competencies could be increased.
\end{abstract}

Key words: problem based learning, physics basic competencies, activity.

\section{Pendahuluan}

Secara umum, kesulitan-kesulitan yang dialami siswa berupa kesulitan yang berasal dari diri siswa itu sendiri yang disebut kesulitan internal dan kesulitan yang berasal dari luar diri siswa yang disebut kesulitan eksternal. Kesulitan internal itu berupa rendahnya kemampuan kognitif, minat, bakat, dan motivasi siswa. Kesulitan eksternal, itu berupa kurangnya fasilitas, tidak tepatnya strategi belajar yang diterapkan guru, termasuk rendahnya kompetensi guru dalam membelajarkan siswanya. Kegagalan siswa dalam menanggulangi kesulitan belajar yang berimplikasi pada kegagalannya dalam belajar oleh guru hanya ditimpakan kepada siswa sebagai kegagalan dalam menanggulangi kesulitan internalnya saja. Guru jarang melakukan refleksi untuk memahami penyebabpenyebab kegagaglan siswa dalam belajar. Kegagalan siswa mungkin saja diakibatkan oleh kegagalan guru dalam memilih strategi pembelajaran yang tepat, sesuai dengan karakteristik pelajaran atau peserta didik.
Studi awal yang dilakukan pada siswa kelas VIII SMP Amir Hamzah Medan menunjukkan bahwa hasil ulangan umum yang dicapai siswa pada mata pelajaran Fisika sebagai indikator ketercapaian kompetensi kognitif cukup mengecewakan pengajar. Rerta skor pada masing-masing kelas bergerak dari 4,10 - 4,37 dan dengan ketuntasan klasikal bergerak dari $48,6 \%-64,2 \%$.

Hasil interview dengan pengajar Fisika mengungkapkan bahwa kesulitan yang dialami dalam pembelajaran adalah sulit memotivasi dan menumbuhkan minat anak untuk mengerjakan tugas-tugas pembelajaran Fisika. Tugas-tugas yang diberikan sekadar dikerjakan. Bahkan, banyak siswa yang tidak mengerjakan tugastugasnya dengan alasan tidak mengerti atau tidak bisa. Upaya siswa untuk berusaha menyelesaikan tugas di kelas sangat rendah. Interaksi siswa di kelas, baik dengan teman-temannya maupun dengan gurunya, sangat rendah. Siswa yang merasa tidak mengerti dan tidak bisa mengerjakan tugas yang diberikan guru di kelas, 
cenderung diam, bersikap pasif, dan acuh saja terhadap hasil yang dicapai.

Berdasarkan uraian di atas, secara eksplisit, dalam penelitian ini, dapat dikemukakan rumusan masalah yang dipecahkan melalui penlitian ini, yaitu apakah penerapan strategi belajar berbasis masalah dapat meningkatkan pencapaian kompetensi dasar Fisika siswa kelas VIII SMP Amir Hamzah Medan.

Sesuai dengan rumusan masalah di atas, melalui penelitian tindakan kelas dengan menerapkan strategi pembelajaran berbasis masalah, tujuan yang ingin dicapai adalah terjadinya peningkatan capaian kompetensi dasar Fisika siswa kelas VIII SMP Amir Hamzah Medan.

Pelaksanaan penelitian tindakan kelas yang dilaksanakan langsung oleh peneliti yang kebetulan guru Fisika di SMP Amir Hamzah memiliki manfaat dalam mengembangkan pembelajaran Fisika yang sesuai dengan hakikat dan tujuan pembelajaran Fisika. Manfaat yang dimaksud, utamanya, adalah memberi pengalaman pada siswa untuk memecahkan masalah yang ditemukan dalam dunianya dengan konsep-konsep yang dibelajarkan, di samping memberi pengalaman pada peneliti untuk melakukan model-model pembelajaran inovatif yang sesuai tuntutan kurikulum, karakteristik materi yang dibelajarkan dan karakteristik siswa peserta didik yang mengikuti pembelajaran sehingga peneliti dapat memperbaiki langsung cara pengajaran kepada siswa.

Strategi pembelajaran yang dilakukan melalui penelitian ini didasarkan atas kajian teoretis terhadap prinsip belajar. Kaum konstruktivis menyatakan bahwa pengetahuan itu ada dalam diri seseorang yang sedang mengetahui. Pengetahuan tidak dapat dipindahkan begitu saja dari otak seseorang (guru) ke kepala orang lain (siswa). Siswa sendirilah yang harus mengartikan apa yang telah diajarkan dengan menyesuaikannya dengan pengalaman-pengalaman mereka (Suparno, 1997). Piaget mengemukakan, pengetahuan itu dibangun (dikonstruksi) sambil pebelajar mengatur pengelaman-pengalaman yang terdiri atas struktur-struktur mental atau skemataskemata yang sudah ada padanya (Sadia, 2001). Belajar menurut pandangan konstruktivis merupakan modifikasi ide-ide yang ada pada diri siswa. Oleh karena itu, pengertian tentang belajar adalah suatu proses pembentukan pengertian dari pengalaman-pengalaman dalam hubungannya dengan pengetahuan sebelumnya

Pandangan ini mengharuskan terjadinya perubahan paradigma mengajar bukan lagi sebagai proses memindahkan pengetahuan dari guru ke siswa, melainkan suatu kegiatan yang memungkinkan siswa membangun sendiri pengetahuannya. Mengajar berarti partisipasi dengan pebelajar dalam membentuk pengetahuan, membuat makna, mencari kejelasan, bersifat kritis dan mengadakan justifikasi. Mengajar adalah suatu bentuk belajar sendiri (Suparno, 1997). Mengajar menurut pandangan ini adalah membantu seseorang berpikir secara benar dengan membiarkannya berpikir sendiri. Tugas guru adalah membantu siswa agar mampu mengkonstruksi pengetahuannya sesuai dengan situasi yang konkret. Dengan demikian, strategi mengajar perlu juga disesuaikan dengan kebutuhan dan situasi siswa.

Penerapan strategi pembelajaran berbasis masalah merupakan salah satu bentuk upaya agar pada pembelajaran terjadi proses konstruksi pengetahuan pada diri sisiwa, terjadi interaksi yang kondusif dan terjadi pemaknaan pembelajran sesuai dengan dunia nyata siswa. Pembelajaran berbasis masalah yang dikenal dengan problem-based learning (PBL), awalnya dirancang untuk program graduate bidang kesehatan oleh Barrows (1988) yang kemudian diadaptasi untuk program akademi kependidikan oleh Stapein Gallager, (1993). PBL ini dikembangkan berdasarkan teori psikologi kognitif modern yang menyatakan bahwa belajar adalah suatu proses dalam mana pebelajar secara aktif mengkonstruksi pengetahuannya. Dalam belajar, siswa sendirilah yang harus mengkonstruksi pengetahuannya melalui interaksinya dengan lingkungan belajar yang diseting oleh guru sebagai fasilitator pembelajaran (Nur M dan Ibrahim, 2004). Teori yang dikembangkan ini mengandung dua prinsip penting dari makna belajar, yaitu (1) belajar adalah proses konstruktif bukan proses menerima (receptive process) dan (2) belajar dipengaruhi oleh faktor interaksi sosial dan sifat kontekstual dari materi pelajaran. (Wim H. Gijselaers, 1996, Barbara et al. 2002). Strategi belajar berbasis masalah memiliki sejumlah karakteristik yang membedakan dengan strategi belajar lainnya, yaitu (1) pembelajaran bersifat student centered, (2) pembelajaran terjadi pada kelompokkelompok kecil, (3) guru berperan sebagai fasilitator dan moderator, (4) masalah menjadi 
fokus dan stimulus pembelajaran, masalah merupakan sarana mengembangkan secara klinis keterampilan problem solving, dan (5) informasiinformasi baru diperoleh melalui belajar mandiri (self directed learning) (Barrows, 1996, Savoie \& Andrew, 1994).

\section{Metodologi Penelitian}

Penelitian tindakan kelas ini dilaksanakan di kelas VIII - 1 SMP Amir Hamzah mulai dari bulan Agustus 2016 sampai dengan Februari 2017 (6 bulan). Subjek penelitiannya adalah siswa kelas VIII - 1 SMP Amir Hamzah Medan tahun ajaran 2016/2017 dengan jumlah siswa 40 orang. Objek penelitianya adalah kompetensi dasar Fisika. Kompetensi dasar Fisika siswa dimaksud meliputi kompensi kognitif, afektif, dan psikomotor.

Penelitian ini dilaksanakan dalam dua siklus, masing-masing siklus terdiri dari empat tahapan, yaitu: tahap perencanaan tindakan, tahap pelaksanaan tindakan, tahap observasi dan evaluasi, dan tahap refleksi

Data yang dikumpulkan untuk menjawab masalah dalam penelitian ini adalah data kompetensi dasar Fisika siswa yang meliputi tiga aspek, yaitu: kognitif, afektif, dan psikomotor. Instrumen dan metode pengumpulan data ditunjukkan tabel 01.

Tabel 01: Instrumen dan Metode Pengumpulan

Data

\begin{tabular}{|ll|l|l|}
\hline \multicolumn{2}{|c|}{ Jenis Data } & Instrumen & Metode \\
\hline a. Kompetensi Kognitif & Tes pemahaman & Tes \\
b. Kompetensi Afektif & konsep & Kuisioner \\
c. Kompetensi & Angket Sikap & Observasi \\
Psikomotor & Lembar & \\
\hline
\end{tabular}

Tes pemahaman konsep sebagai instrumen pengumpulan data pemahaman konsep siswa terhadap konsep-konsep dan prinsip-prinsip Fisika disusun dalam bentuk pilihan ganda diperluas (Santyasa, 2005) dengan jumlah soal sebanyak 15 butir. Skor maksimum setiap butir soal adalah 4 dan skor minimum adalah 0.

Data kompetensi psikomotor dikumpulkan dengan menggunakan lembar observasi. Indikator yang dinilai ada 5 item dengan nilai tertinggi adalah 5 untuk setiap item dan nilai terendah adalah 1. Jumlah skor maksimumnya adalah 25 dan jumlah skor minimumnya adalah 5 .

Kuesioner sikap siswa digunakan untuk mengumpulkan data tentang sikap siswa terhadap pembelajaran yang diterapkan yaitu strategi belajar berbasis masalah. Kuesioner sikap ini diberikan setiap akhir siklus. Angket sikap disusun dalam bentuk pernyataan-pernyataan dengan masing-masing lima pilihan sesuai pola Likert

Data aspek kompetensi kognitif dianalisis secara deskriptif dengan menentukan skor rerata, standar deviasi, dan ketuntasan klasikal, dengan indikator ketercapaian rerata skor kompetensi kogntitif minimal 65 dengan ketuntasan klasikal lebih besar atau sama dengan 85\%. Data psikomotor dan data afektif siswa dianalisis secara deskriptif dengan menentukan kategori skor rererata kedua data aspek kompetensi psikomotor dan afektif yang dicapai siswa. Kriteria keberhasilan untuk kompetensi psikomotor adalah rerata skor psikomotor siswa minimal berada pada kategori baik, sedangkan kriteria keberhasilan kompetensi afektif siswa minaml berada pada kategori positif.

\section{Hasil Penelitian dan Pembahasan}

Hasil penelitian ini menguraikan hasil yang diperoleh selama tindakan dari siklus I dan II berupa capaian kompetensi dasar Fisika siswa, yang meliputi (1) kompetensi afektif, (2) kompetensi kognitif, dan (3) kompetensi psikomotor.

Pelaksanaan penelitian tindakan kelas pada siklus I diikuti oleh sebanyak 40 orang siswa dengan materi yang dibelajarkan suhu dan kalor, yang dikemas dalam 2 skenario pembelajaran. Di awal kegiatan pembelajaran, guru terlebih dahulu menyampaikan kepada siswa strategi belajar diterapkan. Guru menyampaikan tujuan dan garis besar materi yang dibelajarkan. Guru menyampaikan sebuah masalah nyata tentang suhu dan kalor kepada siswa. Dalam memecahkan masalah guru mengorganisasikan siswa menjadi 8 kelompok heterogen berdasarkan keanekaragaman gender dan perbedaan kemampuan akademiknya.

Hasil Penelitian pada siklus I adalah sebagai berikut. Berdasarkan tes pemahaman konsep yang dilaksanakan pada akhir siklus pembelajaran sebagai indikator capaian kompetensi kognitif pada siklus I ada dalam rentangan 48,75 sampai 78,00 dengan skor rerata sebesar 64,13, standar deviasi 9,44, dan ketuntasan klasikal 55,0\%. Berdasarkan kriteria keberhasilan capaian kompetensi kognitif, hasil capaian kompetensi kognitif pada siklus I penelitian ini belum mencapai kriteria keberhasilan. 
Hasil analisis data skor kompetensi psikomotor siswa pada siklus I menunjukkan bahwa skor rerata psikomotor siswa sebesar 18,09 dengan standar deviasi 0,80 yaitu berada pada kategori tinggi. Sebaran nilai aspek psikomotor siswa pada masing-masing kategori ditunjukkan melalaui tabel 02.

Tabel 02 : Sebaran Skor Psikomotor Siswa pada Siklus I

\begin{tabular}{|c|c|c|c|c|}
\hline No & Kelas interval & Kategori & Frekuensi & $\begin{array}{c}\text { Prosentase } \\
(\%)\end{array}$ \\
\hline 1 & $19,99-25,00$ & Sangat tinggi & 2 & 5,00 \\
\hline 2 & $16,67-19,98$ & Tinggi & 38 & 95,00 \\
\hline 3 & $13,33-16,66$ & Cukup tinggi & 0 & 0,00 \\
\hline 4 & $10,01-13,32$ & Kurang tinggi & 0 & 0,00 \\
\hline 5 & $5,00-10,00$ & $\begin{array}{c}\text { Sangat kurang } \\
\text { tinggi }\end{array}$ & 0 & 0,00 \\
\hline
\end{tabular}

Hasil analisis data skor afektif siswa yang diperoleh melalui teknik angket setelah tindakan pada siklus I menunjukkan bahwa skor rerata afektif siswa sebesar 74,05 dengan standar deviasi 7,00. Skor rerata-rerata aspek afektif siswa berada pada kategori tinggi. Sebaran skor afektif siswa sesuai dengan kategori yang telah ditetapkan untuk siklus I ditunjukkan melalui tabel 03.

Tabel 03 : Sebaran Skor Afektif Siswa pada Siklus I

\begin{tabular}{|c|c|c|c|c|}
\hline No. & $\begin{array}{c}\text { Kelas } \\
\text { interval }\end{array}$ & Kategori & Frekuensi & $\begin{array}{c}\text { Prosentase } \\
(\%)\end{array}$ \\
\hline 1 & $80-100$ & Sangat tinggi & 12 & 30,00 \\
\hline 2 & $67-79$ & Tinggi & 19 & 47,50 \\
\hline 3 & $53-66$ & Cukup tinggi & 9 & $22,5 \%$ \\
\hline 4 & $40-52$ & Kurang tinggi & 0 & 0,00 \\
\hline 5 & $20-39$ & $\begin{array}{c}\text { Sangat kurang } \\
\text { tinggi }\end{array}$ & 0 & 0,00 \\
\hline
\end{tabular}

Pelaksanaan tindakan pada siklus II disesuaikan dengan hasil refleksi kegiatan pada siklus I. Kegiatan yang dilakukan dalam proses pembelajaran merupakan penyempurnaan langkah-langkah pembelajaran yang digunakan pada siklus I. Pada siklus II kajian tentang pemuaian dikemas menjadi tiga skenario pembelajaran. Guru dalam berperan sebagai fasilitator dan moderator melakukan team teaching. Sebagai fasilitator team teaching, guru masuk ke masing-masing kelompok untuk melakukan bimbingan secara lebih intensif. Dengan demikian, interaksi siswa pada siklus II ini dengan siswa lain maupun dengan fasilitator tampak lebih kondusif dan mereka tidak canggung-canggung untuk bertanya, sehingga hubungan antar siswa maupun siswa dengan guru menjadi lebih akrab. Team teaching telah dapat memberikan kesempatan bimbingan yang lebih intensif dan mererata kepada masing-masing kelompok. Pada saat berdiskusi dengan anggota kelompok, siswa berusaha sungguh-sungguh untuk dapat memahami apa yang didiskusikan bersama anggota kelompoknya, sehingga siswa yang mendapat tugas menjelaskan hasil diskusinya dapat melakukannya dengan baik.

Hasil penelitian pada siklus II adalah sebagai berikut. Hasil analisis data kompetensi kognitif siswa adalah, skor capaian pemahaman konsep siswa sebagai indikator capaian kompetensi kognitif ada dalam rentangan 61,70 sampai 83,30 dengan skor rerata 74,67 dan standar deviasi 6,05 serta ketuntasan klasikal $87.50 \%$. Berdasarkan kriteria keberhasilan yang telah ditetapkan, kompetensi kognitif yang dicapai ini telah mencapai kriteria keberhasilan.

Dari hasil analisis data skor kompetensi psikomotor siswa di peroleh skor rerata sebesar 20.00 dengan standar deviasi sebesar 0,83 dan berada pada kategori sangat tinggi. Sebaran nilai aspek psikomotor siswa pada masing-masing kategori yang telah ditetapkan ditunjukkan melalui tabel 04

Tabel 04 : Sebaran Nilai Aspek Psikomotor Siswa pada Siklus II

\begin{tabular}{|c|c|c|c|c|}
\hline No & Kelas interval & Kategori & Frekuensi & $\begin{array}{c}\text { Prosentase } \\
(\%)\end{array}$ \\
\hline 1 & $19,99-25,00$ & Sangat tinggi & 22 & 55,007 \\
\hline 2 & $16,67-19,98$ & Tinggi & 18 & 45,00 \\
\hline 3 & $13,33-16,66$ & Cukup tinggi & 0 & 0,00 \\
\hline 4 & $10,01-13,32$ & Kurang tinggi & 0 & 0,00 \\
\hline 5 & $5,00-10,00$ & $\begin{array}{c}\text { Sangat } \\
\text { kurang tinggi }\end{array}$ & 0 & 0,00 \\
\hline
\end{tabular}

Hasil analisis data kompetensi afektif, yang diperoleh dengan teknik angket setelah pelaksanaan tindakan pada siklus II, menunjukkan skor rerata sebesar 82,14 dengan standar deviasi 3,40. Rerata skor kompetensi afektif yang dicapai pada siklus II berdasarkan kriteria keberhasilan yang telah ditetapkan berada pada kategori tinggi. Sebaran capaian kompetensi afektif siswa berdasarkan kategori yang telah ditetapkan ditunjukkan melalui tabel 05 .

Tabel 05 : Sebaran Skor Kompetensi Afektif Siswa Pada Siklus II

\begin{tabular}{|c|c|c|c|c|}
\hline No & $\begin{array}{c}\text { Kelas } \\
\text { interval }\end{array}$ & Kategori & Frekuensi & $\begin{array}{c}\text { Prosentase } \\
(\%)\end{array}$ \\
\hline 1 & $80-100$ & Sangat tinggi & 33 & 82,50 \\
\hline 2 & $67-79$ & Tinggi & 7 & 17,50 \\
\hline 3 & $53-66$ & Cukup tinggi & 0 & 0,00 \\
\hline 4 & $40-52$ & Kurang tinggi & 0 & 0,00 \\
\hline 5 & $20-39$ & $\begin{array}{c}\text { Sangat kurang } \\
\text { tinggi }\end{array}$ & 0 & 0,00 \\
\hline
\end{tabular}

Hasil penelitian yang telah dilaksanakan dalam 2 siklus menunjukkan terjadinya peningkatan dalam capaian skor kompetensi dasar Fisika siswa pada ketiga aspek kompetensi dasar, yang meliputi aspek kompetensi kognitif, 
aspek kompetensi psikomotor, dan aspek kompetensi afektif. Rererata skor kompetensi kognitif siswa pada siklus I sebesar 64.13 dengan standar deviasi 9,44 dan ketuntasan klasikal siswa 55\%. Setelah dilakukannya penyempurnaan pelaksanaan tindakan pada siklus II, dihasilkan capain rererata skor kompetensi kognitif siswa sebesar 74,67 dengan standar deviasi 6,05. Capaian rererata skor kompetensi psikomotor pada siklus I sebesar18,09 dengan standar deviasi sebesar 0,80 mengalami peningkatan pada siklus II dengan skor rerata-rerata mencapai 20.00 dengan standar deviasi 0,83 . Demikian juga capaian kompetensi afektif siswa mengalami peningkatan dari 74,05 dengan standar deviasi 7.0 pada siklus I meningkat menjadi 81,75 dengan standar deviasi 3,75 pada siklus II.

Dari hasil capaian kompetensi dasar Fisika siswa pada siklus I dan siklus II tampak terjadi peningkatan capaian rererata skor kompetensi pada ketiga aspek kompetensi. Hasil ini menunjukkan bahwa penerapan strategi pembelajaran berbasis masalah tidak hanya meningkatkan capaian pada aspek kompetensi kognitif saja, tetapi juga dapat meningkatkan capaian pada aspek kompetensi psikomotor dan aspek kompetensi afektif siswa.

Pembelajaran yang memfokuskan pada proses bagaimana siswa menemukan sendiri konsep-konsep yang dibelajarakan melalui aktivitas siswa mencari sendiri sumber-sumber informasi untuk memecahkan masalah yang diberikan oleh guru pada awal pertemuan memberikan dampak positif pada siswa karena ada dua keuntungan yang diperoleh siswa, yaitu: pertama siswa akan merasa memperoleh tanggung jawab untuk menemukan informasi yang diperlukan untuk memecahkan masalah dan kedua muncul kebiasaan positif pada diri siswa untuk biasa memecahkan masalah dengan menggunakan informasi-iformasi ilmiah yang diperoleh melalui proses pembelajaran. Di samping itu, masalah yang terkait dengan konteks dunia nyata, yang dihadapkan oleh guru pada siswa dapat menumbuhkan minat dan motivasi siswa untuk mempelajari Fisika. Hal ini menumbuhkan kesadaran yang baik pada diri bahwa dunia nyata yang dihadapi siswa dapat dijelaskan melalui pemahaman yang baik terhadap konsep-konsep Fisika yang dipelajari, sehingga dengan berkembangnya kesadaran pada diri siswa akan adanya keterkaitan antara konten yang dipelajarai dengan konteks dunia nyata yang dihadapi siswa akan dihasilkan pemaknaan pembelajaran yang baik pada siswa.

Pendekatan kooperatif sebagai lingkungan belajar yang digunakan pada startegi pembelajaran dengan pendekatan berbasis masalah, akan memberikan peluang yang baik untuk terjadinya kerjasama yang saling menghargai antara sesama kelompok dalam belajarnya. Kondisi ini memberikan dampak positif terhadap terjadinya pemererataan capaian kompetensi dasar Fisika karena, melalui kerja kelompok koopertif akan terjadi saling sharing pengetahuan antara sesama anggota kelompok dalam belajar, dan terjadi aktivitas pembelajaran yang lebih kondusif. Dampak positip yang dihasilkan dari kelompok kooperatif pada capaian kompetensi dasar Fisika ditunjukkan oleh semakin rendahnya standar deviasi pada ketiga aspek kompetensi yang dihasilkan dari siklus I ke siklus II.

Semua dampak positif yang dihasilkan ini sangat diperlukan dalam pembelajaran yang mengarah pada berpusatnya aktivitas pembelajaran pada siswa dan menjadikan pembelajaran bermakna bagi kehidupan siswa. Dampak yang dihasilkan sesuai dengan dua prinsip penting dari makna belajar berbasis masalah, yaitu; belajar adalah proses konstruktif bukan proses menerima dan dipengaruhi oleh faktor interaksi sosial serta sifat kontekstual dari materi pelajaran. Pandangan ini mengisyaratkan bahwa, dalam pembelajaran, terdapat proses konstruksi pengetahuan oleh pebelajar, terjadi interaksi sosial baik antarsiswa maupun antara siswa dan guru, dan bahan pelajaran yang dipelajari siswa haruslah bersifat kontekstual. Dengan kedua prinsip penting yang terkandung dalam PBL, maka guru yang membelajarkan Fisika dengan PBL mampu memberikan kesempatan yang luas kepada siswa untuk bisa mengkonstruksi sendiri pengetahuan yang ingin dipelajari. Di samping itu, guru juga sebagai fasilitator yang akan memberikan kondisi untuk terjadinya interaksi sosial yang kondusif antar siswa dengan siswa dan antar siswa dengan guru, guru juga memberikan kesempatan kepada siswa untuk melakukan interaksi dengan sesama teman dan memacu keberanian siswa untuk mengemukakan masalah-masalah maupun pandangan-pandangan yang dimiliki siswa sesuai dengan kemampuan yang ada pada diri siswa serta yang terpeting guru berinovasi untuk menggunakan lingkungan sebagai sumber belajar. 


\section{Kesimpulan}

Berdasarkan hasil dan pembahasan penelitian yang diuraikan di atas, pada bagian ini dapat dikemukakan simpulan dari penelitian ini, yaitu penerapan strategi pembelajaran berbasis masalah dapat meningkatkan kompetensi dasar Fisika siswa kelas VIII - 1 SMP Amir Hamzah Medan. Hal ini ditunjukkan oleh peningkatan capaian pada ketiga aspek kompetensi dari siklus I ke siklus II.

Berdasarkan hasil penelitian yang diperoleh dalam penelitian tindakan kelas ini, dapat diajukan saran-saran sebagai berikut. Pertama, dalam menerapkan pembelajaran menggunakan strategi pembelajaran berbasis masalah, guru dianjurkan terlebih dahulu untuk mengeksplorasi masalah-masalah kontekstual mengenai materi yang akan dibelajarkan, agar dapat menumbuhkan motivasi dan ketertarikan siswa pada materi tersebut. Kedua, dalam penerapan strategi belajar berbasis masalah, proses pembelajaran Fisika hendaknya lebih memberikan kebebasan kepada siswa untuk dapat aktif menemukan pengetahuan melalui interaksi dengan lingkungan belajarnya dan dianjurkan pada fasilitator agar membentuk team teaching untuk dapat memberikan bimbingan secara lebih menyeluruh dan mererata pada masing-masing kelompok.

\section{DAFTAR PUSTAKA}

Barbara. J. Duch. Deborah E. allen and Harold B. White, III.2002. Problem-based learning : preparing student succed in the 21 st century. University of Dalaware. http://www.podnetwork.org

Boud, D. and Feletti, G. 1997. The challenge of problem based learning. London. Kogan

Barrows Howard. 1996. New Direction for Teaching and Learning "Problem-Based Learningin Medichine and Beyond; Abrief Overview" . Jossey Bass Publishers

Davis, P. R. Intregrating a problem-based $\begin{array}{ll}\text { learning approach into } \\ \text { undergraduate } & \text { teaching. }\end{array}$
Departement of Construcction and Planning.pdavis@ arch.curtin.edu.au

Depdiknas. 2004. Standar kompetensi mata pelajaran sains. Jakarta: Dirjen Pendidikan.

Dorothy L. Gabel. 1994. Handbook Of Research On Science Teaching and Learning $(A$ Project of the National Science Teachers Association). Macmillan Publishing Company. New York.

Gallagher et al. 1995. Shool Science and Mathematics "Implementing Problem-based Learning in Science Classrooms" Chicago Academy of Science.

Heller,P. et al. 1992. Teaching Problem Solving Through Copertaive grouping Part 1: Group Versus individual Problem Solving. American Journal physics . July 1992 (627 - 636).

1992. Teaching Problem Solving Through Copertaive grouping Part 2: Designing Problem and Structuring Groups. American Journal physics . July 1992 (637 - 644).

Ibrahim, M dan Nur, M. 2000. Pengajaran berdasarkan masalah. Surabaya;UNESA-University Press Surabaya.

Ibrahim, M dan Nur, M. 2004. Pengajaran berdasarkan masalah. Surabaya;UNESA-University Press Surabaya.

Santyasa I. W. 2003. Assesmen Dan Kriteria Penilaian Hasil Belajar Fisika Berbasis Kompetensi. Makalah Disajikan Dalam Semlok Bidang Peningkatan Relevansi Progrm DUELike Jurusan Pendidikan Fisika IKIP Negeri Singaraja.

Savoie J M. \& Andrew S H, 1994. " ProblemBased Learning As Classroom Solution" Educational Leadership

Stepien W \& Gallagher S. 1993. " ProblemBased Learning As Authentic at It Gets" Educational Leadership

Suparno, P. 1997. Filsafat konstruktivisme dalam pembelajaran. Yogyakarta. Kanisius. 